\title{
Editorial Comment on Volume 12
}

\author{
SYLVIA L. THRUPP
}

CSSH continues to range widely through space and time, probing pockets of evidence on comparable problems in the articulation of social groups and in their role in shaping and reshaping cultural expression. The selection is always of evidence that is descriptively rich enough to permit some testing of explanatory theory. In a methodological review article on recent trends in evolutionary thought, Conrad Kottak presses home a point which has been stressed in the journal from the start: 'Intensive analysis of single societies, without a comparative framework, describes, but cannot explain socio-cultural differences. Differences as well as similarities must be explained' (12:1: 108).

One of the problems scheduled for discussion in the coming year has occasioned some clashes of opinion this year. Abstractly, it could be styled the problem of conceptualizing continuity and discontinuity in society and culture. Nancie Gonzalez encounters it in trying to clarify and defend her own identification of a Black Carib community in which she has done fieldwork, as a virtually traditionless society of a form 'new under the sun'. Her own answer to her own question as to when a society ceases to be 'traditional' is in the Weberian tradition of contrasting validation by reference to the past with validation by the present (12:1:3). In this regard it recalls Edward Shils' observations on the traditions of intellectuals in our very first issue ( $\mathrm{I}: 1$ : especially pp. 15-16). It might be worth while considering whether the method of $S$. N. Eisenstadt's observations on the dynamics of traditions (11:4: 451-75) might not be applicable, although they deal with complex societies and special kinds of elite leadership, to the small communities studied by fieldwork.

No reply to Richard Fox's attack on scholarship in the Indian field for its stress on the continuity of cultural traditions in India (12:1: 59-72) was offered, and none was invited, since the attack appears to challenge almost any possibility of vigorous cultural continuity surviving structuralfunctional change. $C S S H$ has sponsored other work on the subject in its Supplement III, Caste and Social Mobility in India (Mouton, 1968, obtainable in the U.S.A. from Humanities Press, Inc.) edited by James S. Silver- 
berg, and will present further empirical work on India in the near future.

Another clash of opinion has turned on differing approaches to recognition of a class. Manfred Halpern winds up his prolonged controversy with Amos Perlmutter over the existence of a new middle class in Egypt capable of constructive innovation (X:1, 11:1, 12:1) by stating that all societies today face chaos. The crucial question, which the controversy has sharpened, is, 'Where and under what conditions do innovators form a new class of men?' Still another clash has concerned interpretation of the opposite situation, one in which innovators have been conspicuously absent. Edward Banfield ably defends his now celebrated thesis rooting the cause of rural stagnation in southern Italy in 'amoral familism', at least in the community which he studied, while at the same time inviting fresh criticism on historical grounds $(12: 3: 327-59)$. This is in the true spirit of CSSH. Perhaps there has always been some tradition of amoral familism: the question is how, and in what circumstances, it is modified or transcended. Sydel F. Silverman's paper in the same issue offers some historical background for central Italy, and our already long series on different aspects of peasant societies (identified by subject in the cumulative index to our first ten volumes published in 11:4) will be extended.

Two other papers, Frederick C. Gamst's and Paul Wheatley's, plunge more deeply into history to deal with the limited role of urbanization in Ethiopia as against its prominent role in Yoruba. Both revive some of the theoretical issues dealt with so critically by the late Francisco Benet (VI:1 : 1-23). Gamst takes an opposite view to that developed by myself and by John Freedman in regard to the creative civilizational role of cities (IV: 53-64 and 86-103), stressing the independence of the early Ethiopian state from city centers. The point turns partly, however, on his emphasis on the small size of Ethiopian settlements in the region he has studied. They were in the same range as Western European cities and towns between the ninth century and the twelfth, and the rural situation as he describes it was very similar.

Space does not allow for adequate comment on other historical contributions-Dorothy C. Wertz's on the fleeting appearance of Mankind as a Type-Figure on the late medieval popular religious stage $(12: 1: 83-$ 94), R. T. Lenaghan's view of fourteenth-century English society through the eyes of Chaucer, in the same issue, Donald Birn's case-study of open diplomacy and David Singer's projection from it of possible strategic developments in the future (12:3: 297-326). Kees W. Bolle and Shlomo A. Deshen in the third issue interestingly present two approaches to the question of secularization as a problem within religious systems which differ both from each other and from earlier sociological views in VI and VII. Both Bolle's and Deshen's papers play very closely into the discussions of tradition mentioned above. 
CSSH maintains its policy of keeping up a dialogue between historians, literary scholars, and social scientists without identifying the particular discipline to which any particular contributor officially belongs. The proportion of historians among our writers remains consistently at about a third of the total number of contributors in any given year. The collaboration remains a happy one. 